\title{
Physiological responses of lima bean subjected to salt and water stresses
}

\author{
João V. Pereira Filho ${ }^{1}$, Thales V. de A. Viana², Geocleber G. de Sousa ${ }^{3}$, Keivia L. Chagas², \\ Benito M. de Azevedo² \& Carmem C. M. de S. Pereira ${ }^{4}$
}

${ }^{1}$ Universidade Estadual do Piauí. Uruçuí, PI, Brasil. E-mail: joao_valdenor@hotmail.com (Corresponding author) - ORCID: 0000-0001-9018-5755

${ }^{2}$ Universidade Federal do Ceará. Fortaleza, CE, Brasil. E-mail: thales@ufc.br - ORCID: 0000-0003-0722-6371; kei-via@hotmail.com - ORCID: 00000002-1293-6637; benito@ufc.br - ORCID: 0000-0001-7391-1719

${ }^{3}$ Universidade da Integração Internacional da Lusofonia Afro-Brasileira. Redenção, CE, Brasil. E-mail: sousagg@unilab.edu.br - ORCID: 0000-00000002-1466-6458

${ }^{4}$ Universidade Federal Rural de Pernambuco. Recife, PE, Brasil. E-mail: crismareco@hotmail.com - ORCID: 0000-0003-1654-3168

\begin{abstract}
Under water deficit and/or salt stress conditions, crops suffer from several physiological disturbances, which lead to the reduction in growth and, consequently, decreases in their yields. Thus, the objective of this study was to evaluate the physiological responses of lima bean, cultivar Espírito Santo, under different irrigation water salinity associated to two water regimes. The experiment was carried out in the experimental area of the Universidade Federal do Ceará, Brazil, from September to November 2017, and it was carried out in pots in full sun, under a completely randomized design in split plots, where water salinities $\left(1.1,2.1,3.1,4.1\right.$ and $\left.5.1 \mathrm{dS} \mathrm{m}^{-1}\right)$ were considered as the plots, and the treatments of water regime (50 and $100 \%$ of the reference evapotranspiration - ETo) were considered as the subplots. At 45 days after sowing, leaf gas exchanges and relative index of total chlorophyll (SPAD index) were evaluated. In general, the increase of salt concentration in irrigation water causes reductions in the physiological responses of lima beans. Under a water regime of $50 \% \mathrm{ETo}$, the instantaneous and intrinsic water use efficiency is higher.
\end{abstract}

Key words: Phaseolus lunatus L., photosynthesis, water quality, water deficit

\section{Respostas fisiológicas da cultura da fava submetida a estresse salino e hídrico}

RESUMO: Sob condições de déficit hídrico e/ou estresse salino as culturas sofrem diversos distúrbios fisiológicos, que levam à redução no crescimento e, consequentemente, decréscimos em seus rendimentos agronômicos. Neste sentido, o objetivo do trabalho foi avaliar as respostas fisiológicas da cultura da fava, cultivar Espírito Santo, sob diferentes salinidades da água de irrigação associadas a dois regimes hídricos. O experimento foi conduzido na área experimental da Universidade Federal do Ceará, no período de setembro a novembro de 2017, sendo realizado em vasos a pleno sol, sob um delineamento estatístico inteiramente casualizado em parcelas subdivididas, onde as salinidades da água de irrigação $\left(1,1 ; 2,1 ; 3,1 ; 4,1\right.$ e $\left.5,1 \mathrm{dS}^{-1}\right)$ foram consideradas como as parcelas, enquanto os regimes hídricos de 50 e $100 \%$ da evapotranspiração de referência - ETo, as subparcelas. Aos 45 dias após a semeadura avaliaram-se as trocas gasosas foliares e os índices relativos de clorofila total (índice SPAD). De maneira geral, o aumento da concentração de sais na água de irrigação provoca reduções nas respostas fisiológicas do feijão fava. Sob um regime hídrico de 50\% da ETo, a eficiência instantânea e intrínseca do uso da água é maior.

Palavras-chave: Phaseolus lunatus L., fotossíntese, qualidade da água, déficit hídrico 


\section{INTRODUCTION}

Lima bean (Phaseolus lunatus L.) is a leguminous species cultivated in almost all regions of the world, being widely consumed in Latin America, United States, Europe and Asia. In Brazil, it has wide distribution in the national territory, being present in all Brazilian biomes. However, it is cultivated mainly in the Northeast portion, having good adaptation to the semiarid region (Oliveira et al., 2011).

About $90 \%$ of the biological production of plants occurs in response to photosynthetic activity. Increments in stomatal diffusive resistance may cause reduction in the net photosynthesis (Silva et al., 2015). Thus, gas exchange evaluation is an important tool in determining the adaptation and stability of plants to certain ecosystems, because the reduction in plant growth may be related to the reduction in the photosynthetic activity, limited by abiotic factors that are intrinsic to the cultivation site (Caron et al., 2014).

Salinity is a global problem which affects from the processes that are exogenous to the plant to the end of its cycle, and it is important to search for new information regarding the effects that occur on the plant. Due to the various losses caused by salinity in agriculture, it is also necessary to improve management techniques related to soil, water or crops that result in increased tolerance to salinity, which are of great relevance to the maintenance of agricultural yield in soils with excess of salts. Although there are already many studies in the literature, several gaps still need to be fulfilled due to the different effects observed on different plants (Negrão et al., 2017).

Katerji et al. (2011), evaluating the combined effects of salinity $\left(1.0,2.3\right.$ and $\left.3.6 \mathrm{dS} \mathrm{m}^{-1}\right)$ and two water levels indicated by the leaf water potential $(-0.3$ and $-0.6 \mathrm{MPa})$, observed that yield reductions were associated with the increase in the levels of soil salinity, confirming the interaction between the effects of salinity and water deficit on lima bean yield.

In this context, this study aimed to evaluate the physiological responses of lima bean, cultivar Espírito Santo, under different irrigation water salinity associated with two water regimes.

\section{Material ANd Methods}

The experiment was conducted in the experimental area of the Agrometeorological Station of the Departamento de Engenharia Agrícola, belonging to the Universidade Federal do Ceará (UFC), in the municipality of Fortaleza, CE, Brazil, at geographic coordinates $3^{\circ} 45^{\prime} \mathrm{S}, 38^{\circ} 33^{\prime} \mathrm{W}$, and altitude of $19 \mathrm{~m}$, in the period from September to November 2017. The climate of the region, according to Köppen's classification, is Aw', rainy tropical, with high temperatures and predominant rainy season in the autumn.
The substrate for the cultivation of plants consisted of a sample of soil classified as Ultisol, with sandy loam texture, with density of $1.49 \mathrm{~g} \mathrm{dm}^{-3}$, from an area with native vegetation, located close to the experimental area of the Agrometeorological Station. Its chemical characteristics are presented in Table 1.

The statistical design was completely randomized in split plots, where the treatments with salinity levels $(1.1 ; 2.1$; 3.1; 4.1 and $5.1 \mathrm{dS} \mathrm{m}^{-1}$ ) were considered as the plots and the treatment with water regimes (100 and $50 \%$ of the reference evapotranspiration - ETo) were distributed in the subplots, with four repetitions

The total observation area occupied with the lima bean crop was $80 \mathrm{~m}^{2}$, where 80 plastic pots with volume of $14 \mathrm{~L}$ were set up. The plots occupied an area of $20.0 \mathrm{~m}^{2}$, consisting of 20 plots, distributed in five planting rows. The subplots occupied, individually, an area of $10.0 \mathrm{~m}^{2}$, being composed of two pots distributed per planting row in each treatment of water regime.

For planting, seeds of lima bean, cultivar Espírito Santo, were sown in 14-L plastic pots. Planting was done by sowing on average five seeds per pot. At 7 days after sowing DAS), a germination of approximately $90 \%$ was observed. In the thinning, performed manually at 10 DAS, plants were uprooted from the soil, leaving two plants per pot, in order to obtain the plant stand desired by the experiment.

Chemical fertilizers were applied in the soil before planting, based on soil analysis and nutritional requirements of the crop according to the recommendations of Aquino et al. (1993). The required amounts of NPK macronutrients were respectively: $20.0 \mathrm{~kg} \mathrm{ha}^{-1}$ of nitrogen $\left(2 \mathrm{~g} \mathrm{plant}^{-1}\right), 80.0 \mathrm{~kg} \mathrm{ha}^{-1}$ of phosphorus $\left(8\right.$ g plant $\left.^{-1}\right)$ and $30.0 \mathrm{~kg} \mathrm{ha}^{-1}$ of potassium $\left(8 \mathrm{~g} \mathrm{plant}^{-1}\right)$, using urea, monoammonium phosphate (MAP) and potassium chloride as the sources, respectively.

The water used in the irrigation system came from a well and its results of water quality analysis for irrigation purposes were: $1.3 \mathrm{mmol}_{\mathrm{c}} \mathrm{L}^{-1} \mathrm{Ca}^{2+} ; 3.1 \mathrm{mmol} \mathrm{L}_{\mathrm{c}} \mathrm{L}^{-1} \mathrm{Mg}^{2+} ; 4.5 \mathrm{mmol}_{\mathrm{c}} \mathrm{L}^{-1} \mathrm{Na}^{+}$; $0.4 \mathrm{mmol} \mathrm{L}_{\mathrm{c}}^{-1} \mathrm{~K}^{+} ; 5.2 \mathrm{mmol}_{\mathrm{c}} \mathrm{L}^{-1} \mathrm{Cl}^{-}$referring to the cations; 4.3 $\mathrm{mmol}_{\mathrm{c}} \mathrm{L}^{-1} \mathrm{HCO}_{3}^{-}$referring to the anions; $\mathrm{EC}=0.95 \mathrm{dS} \mathrm{m}^{-1}$; $\mathrm{SAR}=3.05 ; \mathrm{pH}=8.0 ;$ dissolved solids $=950 \mathrm{mg} \mathrm{L}^{-1} ; \mathrm{C} 3 \mathrm{~S} 1$ classification. Based on the result, it was found that the water in question had high salinity (C3) and low sodium content (S1).

Reference evapotranspiration - ETo was determined using the methodology proposed by Bernardo et al. (2008), according to Eq. 1:

$$
\mathrm{ETo}=\mathrm{ECA} \times \mathrm{Kp}
$$

where:

ETo - reference evapotranspiration, $\mathrm{mm}$;

ECA - class A pan evaporation, $\mathrm{mm}$; and,

Table 1. Chemical analysis of the soil used as substrate in the experiment

\begin{tabular}{|c|c|c|c|c|c|c|c|c|}
\hline \multicolumn{9}{|c|}{ Sorption complex $\left(\mathrm{cmol}_{\mathrm{c}} \mathrm{kg}^{-1}\right)$} \\
\hline $\mathrm{Ca}^{2+}$ & $\mathrm{Mg}^{2+}$ & $\mathrm{Na}^{+}$ & $\mathrm{K}^{+}$ & & $\mathrm{H}^{+}+\mathrm{Al}^{3+}$ & $\mathrm{A}^{3+}$ & $\mathbf{S}$ & $\bar{T}$ \\
\hline 1.20 & 0.60 & 0.23 & 0.36 & & 1.98 & 0.15 & 2.6 & 4.6 \\
\hline \multirow{2}{*}{$\mathrm{pH}$ in water } & \multirow{2}{*}{$\begin{array}{c}\text { EC } \\
\left(\mathrm{dS} \mathrm{m}^{-1}\right)\end{array}$} & V & M & \multirow{2}{*}{ ESP } & C $\quad$ N & \multirow{2}{*}{$\mathrm{C} \mathrm{N}^{-1}$} & \multirow{2}{*}{$\begin{array}{c}\mathrm{OM} \\
\left(\mathrm{g} \mathrm{kg}^{-1}\right)\end{array}$} & \multirow{2}{*}{$\begin{array}{c}\text { Assimilable P } \\
\left(\mathrm{mg} \mathrm{kg}^{-1}\right)\end{array}$} \\
\hline & & & & & $\left(\mathrm{g} \mathrm{kg}^{-1}\right)$ & & & \\
\hline 6.0 & 0.35 & 57 & 5 & 5 & 0.61 & 11 & 11.17 & 32 \\
\hline
\end{tabular}

S - Sum of bases; T - Cation exchange capacity; $\mathrm{pH}$ - Hydrogen potential; EC - Electrical conductivity of the soil saturation extract; $\mathrm{V}$ - Base saturation; $\mathrm{m}$ - Al saturation percentage; OM - Organic matter; ESP - Exchangeable sodium percentage; Assimilable P - Assimilable phosphorus 
Kp - class A pan coefficient, dimensionless.

Kp was obtained using the equation proposed by Snyder (1992), Eq. 2:

$$
\mathrm{Kp}=0.482+0.024 \ln (\mathrm{F})-0.00376 \mathrm{U}+0.0045 \mathrm{RH}
$$

where:

F - distance from the center of the tank to the edge (tank surrounded by grass at $10 \mathrm{~m}$ );

$\mathrm{U} \quad$ - wind speed at $2 \mathrm{~m}$ height, $\mathrm{km} \mathrm{d}^{-1}$; and,

$\mathrm{RH} \quad$ - average air relative humidity, $\%$.

The climatic data required to calculate Kp were obtained by the arithmetic mean of the last five years, for the months in which the experiment was conducted, being collected at an automated meteorological station, located close to the experimental area.

For the application of irrigation water, in $\mathrm{mL}$, a $1000-\mathrm{mL}$ cylinder was used, and the volume to be applied was calculated according to the pot area and ETo:

$$
\mathrm{Vol}=1000 \times \mathrm{Ap} \times \mathrm{ETo}
$$

where:

$$
\begin{array}{ll}
\text { Vol } & \text { - water volume to be applied, } \mathrm{mL} ; \\
\text { Ap } & \text { - pot surface area, } \mathrm{m}^{2} \text {; and, } \\
\text { ETo } & \text { - reference evapotranspiration, } \mathrm{mm} \text {; }
\end{array}
$$

After planting the lima bean seeds, the experiment was irrigated daily with a water depth equivalent to $100 \%$ of the reference evapotranspiration - ETo, in order to ensure the initial establishment of the crop until the treatments began to be differentiated, which occurred at 10 days after planting - DAP, through the variation of the irrigation water salinity levels, with an irrigation interval of two days.

In tanks with capacity for $310 \mathrm{~L}$, the quantity of the salts $\mathrm{NaCl}, \mathrm{CaCl}_{2} \cdot 2 \mathrm{H}_{2} \mathrm{O}, \mathrm{MgCl}_{2} \cdot 6 \mathrm{H}_{2} \mathrm{O}$, used to prepare the irrigation waters, was determined in such a way to obtain the desired ECw level in the proportion of 7:2:1, following the relationship between ECw and the salt concentration $\left(\right.$ mmolc $^{-1}=\mathrm{EC} \mathrm{x} \mathrm{10),}$ according to Rhoades et al. (2000).

The relative indices of total chlorophyll (SPAD index) were determined in each experimental unit, in the third leaf counted from the base, at 45 DAP, using a portable meter (SPAD 502,
Minolta Co, Ltd, Osaka, Japan), and the results were expressed in the reading units of the device (SPAD units).

Net photosynthesis (A), transpiration (E) and stomatal conductance (gs) rates were determined using an infrared gas analyzer (IRGA, Mod. Li-COR ${ }^{\oplus} 6400$ XT). The measurements were performed during the period from 8 to $11 \mathrm{~h}$ under ambient conditions of air relative humidity, temperature and radiation.

Gas exchange data were used to determine the instantaneous water use efficiency, calculated by the ratio between photosynthesis and transpiration $(\mathrm{A} / \mathrm{E})$, and the intrinsic water use efficiency, calculated by the ratio between photosynthesis and stomatal conductance (A/gs).

The data were subjected to analysis of variance by $F$ test ( $p$ $\leq 0.05$ and $\leq 0.01$ ) and regression, using the statistical program ASSISTAT 7.6 Beta (Silva \& Azevedo, 2016).

\section{Results AND Discussion}

The ANOVA results presented in Table 2 indicate that all physiological variables were significantly influenced by the interaction between salinity and water regimes $(p \leq 0.01)$, except for the relative index of total chlorophyll, which was significantly affected by the single factors salinity and water regime.

Figures $1 \mathrm{~A}$ and $\mathrm{B}$ present the mean relative indices of total chlorophyll, as a function of water salinities and water regimes, respectively. The results showed a reduction in the relative indices of total chlorophyll (SPAD index), as the irrigation water salinity levels increased and as the imposed water regimes decreased from 100 to $50 \%$ ETo.

The unit increments of the irrigation water salinities cause deleterious effects on the chlorophyll index, compromising the SPAD index values. Thus, the total chlorophyll indices decreased linearly by approximately $20 \%$ between the minimum limit $\left(1.1 \mathrm{dS} \mathrm{m}^{-1}\right)$ and the maximum limit $\left(5.1 \mathrm{dS} \mathrm{m}^{-1}\right)$ of the irrigation water electrical conductivity, with reductions of 1.844 SPAD units, for every unit increase in water salinity.

The reductions in chlorophyll index may be related to the excess of salts, stimulating the enzymatic activity of chlorophyllase, which degrades the molecules of the photosynthesizing pigment and induces the structural destruction of chloroplasts, also leading to imbalance and loss of activity of pigmentation proteins (Taiz et al., 2017).

Silva et al. (2014) also claim that this effect can be attributed

\begin{tabular}{|c|c|c|c|c|c|c|c|}
\hline \multirow{2}{*}{ SV } & \multirow{2}{*}{ DF } & \multicolumn{6}{|c|}{ Mean squares } \\
\hline & & SPAD & $\bar{A}$ & as & $\mathbf{E}$ & A/E & A/as \\
\hline Salinity (S) & 4 & $74.75^{\star}$ & $156.47^{\star \star}$ & $0.013^{\star \star}$ & $9.06^{\star \star}$ & $4.21^{\star \star}$ & $1836.91^{\star \star}$ \\
\hline Residual & 15 & 16.72 & 1.57 & 0.010 & 0.14 & 0.07 & 69.16 \\
\hline Plots & 19 & & & & & & \\
\hline Water regime (I) & 1 & $73.78^{* *}$ & $102.54^{* *}$ & $0.001^{* *}$ & $9.55^{\star \star}$ & $0.49^{* *}$ & $801.61^{* *}$ \\
\hline Interaction S x I & 4 & $5.55^{\mathrm{ns}}$ & $13.52^{* *}$ & $0.002^{\star *}$ & $1.09^{* *}$ & $0.39^{* *}$ & $1113.03^{* \star}$ \\
\hline Residual & 15 & 6.65 & 0.57 & 0.001 & 0.07 & 0.03 & 46.43 \\
\hline Total & 39 & & & & & & \\
\hline CV - S (\%) & & 12.19 & 17.73 & 16.26 & 19.84 & 7.53 & 8.24 \\
\hline$C V-I(\%)$ & & 7.69 & 10.73 & 9.95 & 14.67 & 5.55 & 6.75 \\
\hline
\end{tabular}
to the reduction in the biosynthesis of chlorophylls and may

Table 2. Summary of the analysis of variance for data on the relative index of total chlorophyll (SPAD index) and leaf gas exchanges in the initial growth of lima beans, cultivar Espírito Santo, cultivated under different irrigation water salinities associated with two water regimes

SV - Sources of variation; DF - Degrees of freedom; ${ }^{*}$ - Significant by F test at $\mathrm{p} \leq 0.05$; ${ }^{* *}$ - Significant by F test at $\mathrm{p} \leq 0.01 ; \mathrm{ns}-\mathrm{Not}$ significant; CV - Coefficient of variation; A - Net photosynthesis; gs - Stomatal conductance; E - Transpiration; A/E - Instantaneous water use efficiency; A/gs - Intrinsic water use efficiency 


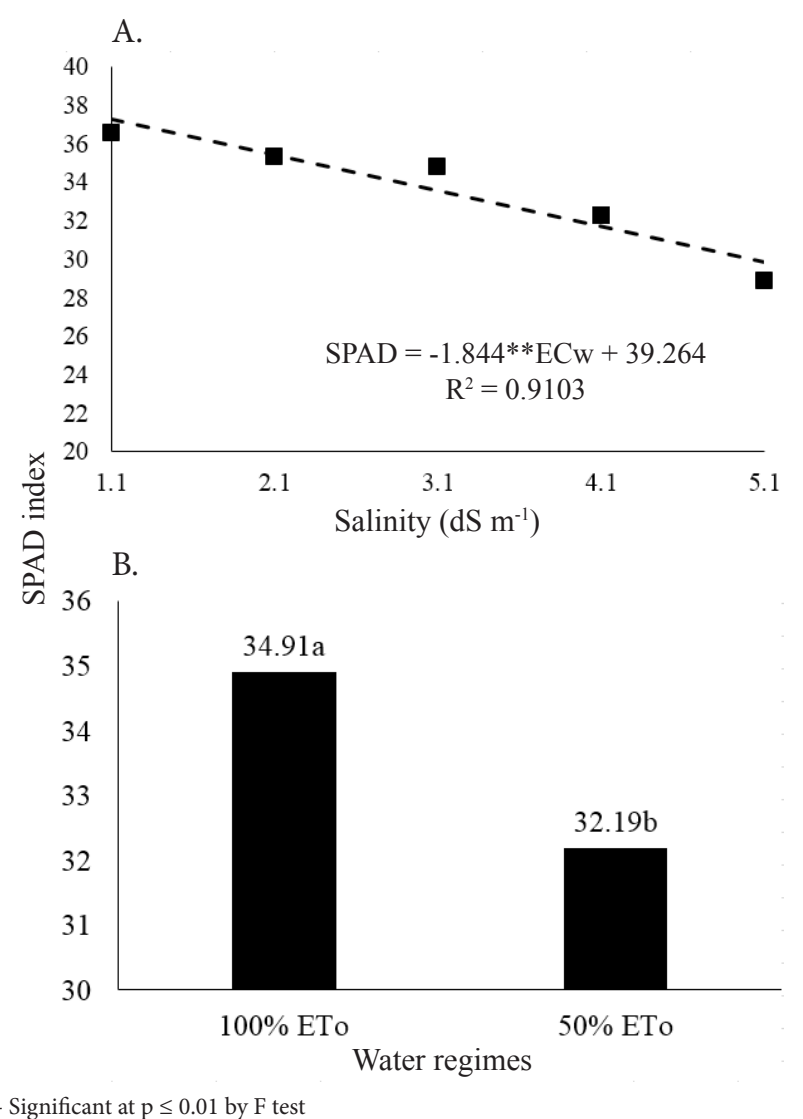

Figure 1. Relative indices of total chlorophyll (SPAD index) in the leaves of lima bean, cultivar Espírito Santo, as a function of water salinities - ECw (A) and irrigation water regimes - \% of ETo (B)

be an acclimation response to salt stress, leading to saving of energy due to the lower capture of light energy and consequently reduction of photo-oxidative stress. These results corroborate those of Silva et al. (2016), who observed that the increase in the concentration of salts resulted in linear reductions in SPAD index readings, when evaluating the effects of soils with increasing levels of electrical conductivity on the relative indices of total chlorophyll in young coconut plants.

Regarding the effect of the water regimes imposed, Figure $1 \mathrm{~B}$ shows that under deficit irrigation conditions (50\% ETo) the mean value of the SPAD index is lower than that in the treatment of full irrigation (100\% ETo). Therefore, it can be inferred that the reduction in SPAD index with the decrease in water supply is a clear consequence of the sensitivity of the relative indices of total chlorophyll of lima bean plants to water stress, which is consistent with Silva et al. (2011), who state that drought stress is usually characterized by loss of chlorophyll, associated with a progressive decline in the photosynthetic capacity of plants.

Carlin et al. (2012) point out that reductions in chlorophyll concentration have been found in plants under water stress, characterizing an indication of oxidative stress, probably resulting from photo-oxidation of pigments, associated with the degradation of chlorophyll molecules. These observations agree with Nascimento et al. (2012), who reported that salt stress causes imbalances between production and removal of reactive oxygen species (ROS). For the authors, the final result of this imbalance is an increase in ROS levels, to the point of triggering oxidative stress, leading to a series of negative implications for the metabolic mechanisms associated with photosynthetic processes.

Figure 2 presents the regressions of the interactions associated with the respective mathematical models which describe the functional relationships between the factors under study for the variables net photosynthesis (Figure 2A), stomatal conductance (Figure 2B), transpiration (Figure 2C), instantaneous water use efficiency (Figure 2D) and intrinsic water use efficiency (Figure 2E) in response to combinations of water salinities and irrigation water regimes.

Linear regression equations fitted to the data related to net photosynthesis, meaning that, as the levels of irrigation water salinity increased, there was a reduction in the net photosynthesis rates of lima bean, with reductions of approximately 3.576 and $1.993 \mu \mathrm{mol} \mathrm{CO}_{2} \mathrm{~m}^{2} \mathrm{~s}^{-1}$ for a $1 \mathrm{dS} \mathrm{m}^{-1}$ increase, under the water regimes of 100 and 50\% ETo, respectively (Figure 2A).

The highest photosynthetic rates were obtained with the control of water deficit, corresponding to the $100 \%$ ETo water regime, at the lowest salinity evaluated $\left(1.1 \mathrm{dS} \mathrm{m}^{-1}\right)$. On the other hand, lower photosynthetic rates were measured with the water regime corresponding to a water deficiency level of 50\% ET, in association with the irrigation water characterized by having the highest salinity level $\left(5.1 \mathrm{dS} \mathrm{m}^{-1}\right)$.

Similar results are presented by Prazeres et al. (2015), who evaluated the physiological responses of two cowpea cultivars irrigated with saline water without water stress and found that salt stress reduced the photosynthetic rate of the plants.

The reductions observed between the treatments of lowest $\left(1.1 \mathrm{dS} \mathrm{m}^{-1}\right)$ and highest $\left(5.1 \mathrm{dS} \mathrm{m}^{-1}\right)$ salt concentrations in the irrigation water were approximately 90.34 and $84.24 \%$, for the imposed water regimes of 100 and 50\% ETo, respectively. The results found reveal a higher resistance of the lima bean crop under conditions of saline environment when irrigated at the normal level of water replacement (100\% ETo), which suggests the existence of a higher photosynthetic potential.

Figure $2 \mathrm{~B}$ shows a decrease in the stomatal conductance of lima bean plants with increased levels of irrigation water salinity when cultivated under water regimes of 100 and 50\% ETo, being best represented by a linear model under both water regimes studied. Thus, such inferences may justify the survival capacity of the plants under the associations between the levels of the stressing agents water deficit and EC. Hence, it is supposed that the regulation of stomatal opening and, consequently, the control of water loss, are mechanisms adopted by some plant species to adjust to the adverse conditions (Taiz et al., 2017).

Prazeres et al. (2015) state that the high salinity of irrigation water has a detrimental effect on stomatal opening, for increasing the resistance to $\mathrm{CO}_{2}$ diffusion. Sousa et al. (2014) also observed a reduction in stomatal conductance in cowpea plants subjected to salt stress.

Cruz et al. (2003) point out that, when plants are subjected to saline conditions, they tend to close the stomata, reducing the amount of transpired water, which can contribute to the reduction in the absorption and transport of toxic ions, such as $\mathrm{Na}^{+}$and $\mathrm{Cl}^{-}$, to their interior, constituting another adaptive strategy of survival under the predominance of these stress conditions.

The present results indicate that the reductions in stomatal conductance may partially compromise the photosynthetic activity. However, based on the inferences of Orsini et al. (2012), 
A.

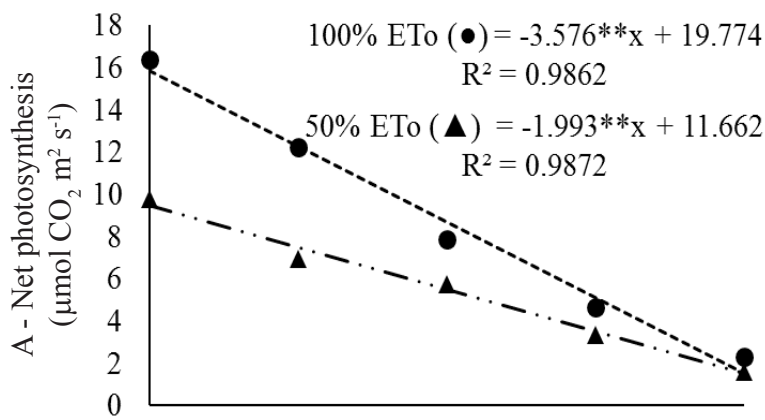

B.

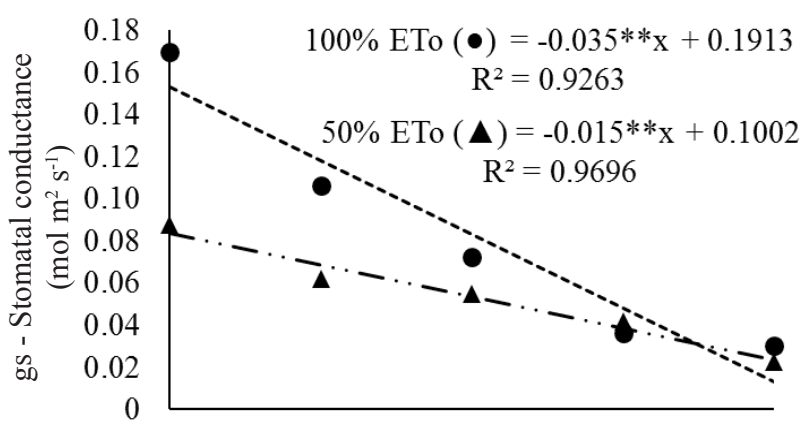

C.

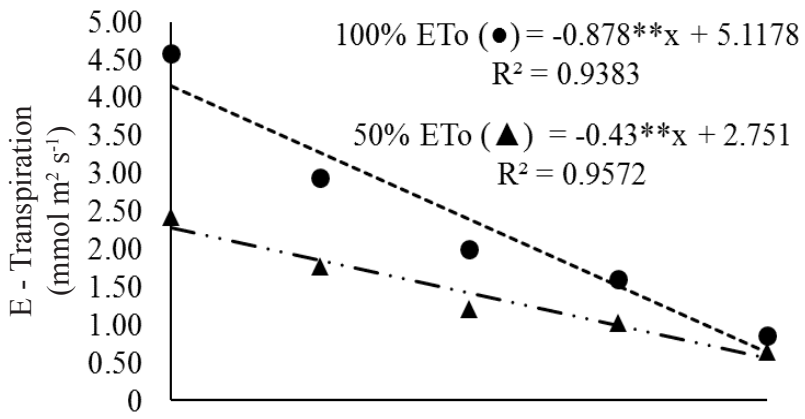

D.

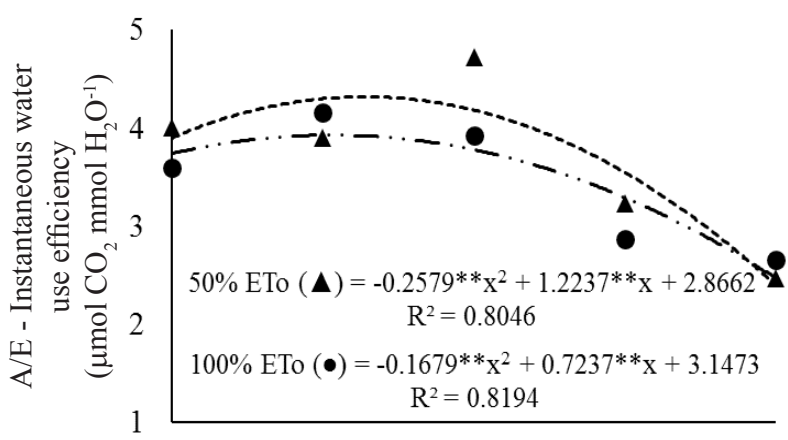

E.

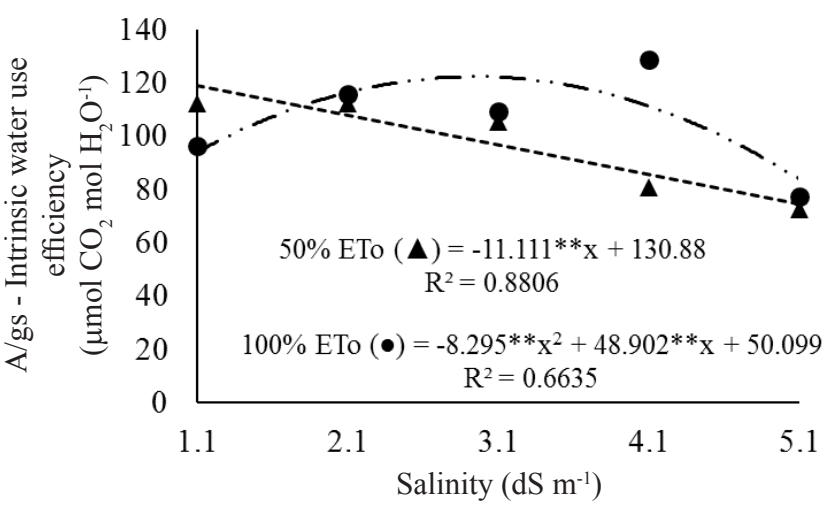

** - Significant at $\mathrm{p} \leq 0.01$ by $\mathrm{F}$ test

Figure 2. Net photosynthesis - A (A), stomatal conductance - gs (B), transpiration - E (C), instantaneous water use efficiency $\mathrm{A} / \mathrm{E}(\mathrm{D})$ and intrinsic water use efficiency - A/gs (E) in leaves of lima beans, cultivar Espírito Santo, as a function of water salinities and irrigation water regimes it can be considered that such responses can also protect plants from rapid dehydration, guaranteeing their survival under stress conditions. Moreover, through stomatal regulation, plants can avoid the incidence of a series of manifestations of other signs that would further affect their respective agronomic performances.

According to Figure 2C, the effects of the salts present in irrigation water caused a linear reduction in the transpiration of lima bean, cultivar Espírito Santo. The superiority of transpiration values in the control level of water supply $(100 \%$ $\mathrm{ETo}$ ) under the water regime of $50 \% \mathrm{ETo}$, are related to the higher water availability to these plants under such water conditions (Silva et al., 2016). Confirming this result, Sousa et al. (2014), when evaluating gas exchange in cowpea under different concentrations of salts in irrigation water, also found a negative effect on transpiration.

The reductions of transpiration between the treatments of lowest $\left(1.1 \mathrm{dS} \mathrm{m}^{-1}\right)$ and highest $\left(5.1 \mathrm{dS} \mathrm{m}^{-1}\right)$ irrigation water salinity were 84.58 and $75.50 \%$, for the water regimes of 100 and $50 \%$ ETo, respectively, where it can be noted that, under lower water availability, the plant begins to reduce its transpiration rate to reduce water loss and save water available in the soil (Figure 2C).

Thus, the results obtained under water regime of $100 \%$ ETo demonstrate that transpiration can be used as a variable to study the water relations of lima bean, since it is a good indicator of water availability in the plant. It is worth remembering that in a situation of good water availability, cultivated plants generally exhibit high transpiration (Fernandes et al., 2015).

Silva et al. (2013) emphasize that solutes dissolved in the root zone generate a lower osmotic potential, which reduces the total soil potential. Hence, the development of plants is hampered and more energy is required by the plant (osmotic adjustment) to generate more negative potentials than that found in soils for water absorption.

According to Silva et al. (2011), the reduction in transpiration for the most part can be caused by the toxic effects of the salts absorbed by plants and by the reduction in the total water potential caused by the increase in salt concentration. In contrast, Soares et al. (2015) add that salt stress can reduce the amount of transpired water and may contribute to a reduction in the absorption and transport of $\mathrm{Na}^{+}$and $\mathrm{Cl}^{-}$ions to the inside of the plants.

A second-degree regression model was fitted to the instantaneous water use efficiency (A/E) for both water regimes imposed, with the increase in the salt concentration of irrigation water (Figure 2D). The maximum values of $\mathrm{A} / \mathrm{E}$, estimated through the derivative of the equation, were obtained at the salinity of 2.15 and $2.37 \mathrm{dS} \mathrm{m}^{-1}$, for the water regimes of 100 and $50 \%$ ETo, respectively.

Silva et al. (2016) describe that plants with higher water use efficiency under salt stress can be saved by the mechanism of exclusion of salts by the roots, because lower values of transpiration directly lead to reductions in soil water consumption.

In general, at the water deficit level of $50 \% \mathrm{ETo}$, the lima bean showed higher instantaneous water use efficiency, which suggests a lower water consumption per assimilated carbon dioxide unit. In contrast, the expression of the magnitude of the response was 
ultimately suppressed, due to the effects of the increase in the salt concentration of the irrigation water (Figure 2D).

Similarly, Soares et al. (2013) also found that the instantaneous water use efficiency was negatively affected by salinity in cowpea plants, cv. BRS Pajeú.

According to Silveira et al. (2013) the instantaneous water use efficiency, besides being influenced by environmental factors, such as water deficit and irrigation water salinity, is highly variable as a function of the type of carbon metabolism of the species.

The responses obtained for intrinsic water use efficiency (A/ gs) under the interactions between water salinity and irrigation water regimes are presented in Figure 2E, with a decreasing linear response and a second-degree polynomial response, as the concentration of salts in irrigation water increased, under the adopted water regimes of 50 and $100 \%$ ETo, respectively.

From the results, it was estimated that in plants subjected to the treatment corresponding to water deficit level of $50 \%$ ETo, there were reductions in the values of intrinsic water use efficiency of $11.111 \mu \mathrm{mol} \mathrm{CO} \mathrm{mol} \mathrm{H}_{2} \mathrm{O}^{-1}$, for every unit increase in irrigation water EC. For plants irrigated under a regime of $100 \% \mathrm{ETo}$, it was estimated by the derivative of the equation that the maximum value of $\mathrm{A} / \mathrm{gs}$ was $122.33 \mu \mathrm{mol} \mathrm{CO} \mathrm{mol} \mathrm{H}_{2} \mathrm{O}^{-1}$ under an irrigation water EC of $2.95 \mathrm{dS} \mathrm{m}^{-1}$ (Figure 2E).

Similar results were observed by Lacerda et al. (2009), who found that the intrinsic water use efficiency also decreased linearly with the increase of salinity in cowpea plants and by Passos et al. (2005), who observed that under conditions of water scarcity, the coconut tree showed a significant increase in the values of intrinsic water use efficiency (A/gs).

This behavior can be justified based on the inferences proposed by Taiz et al. (2017), who discuss that stomatal opening and closure regulate leaf gas exchanges, which promote water loss as a result of the entry of $\mathrm{CO}_{2}$. Under stress conditions, drought and/or salinity, the decrease in water loss through the greater degree of stomatal closure also restricts the entry of $\mathrm{CO}_{2}$. For the authors, higher intrinsic water use efficiencies guarantee greater $\mathrm{CO}_{2}$ absorption with minimal water losses.

\section{Conclusions}

1. The relative indices of chlorophyll, net photosynthesis, transpiration, stomatal conductance and instantaneous and intrinsic water use efficiencies of lima bean crop were reduced by the increase in the salt concentration of irrigation water.

2. Net photosynthesis, stomatal conductance and transpiration rates had greater relative reductions under the water regime of $100 \%$ ETo.

3. Under the water regime of $50 \%$ ETo, the lima bean plant had higher instantaneous water use efficiency and, in contrast, the intrinsic water use efficiency had higher results when plants were subjected to the water regime of $100 \%$ ETo.

\section{Literature Cited}

Aquino, A. B.; Aquino, B. F.; Hernandez, F. F. F.; Holanda, F. J. M.; Freire, J. M.; Crisóstomo, L. A.; Costa, R. I.; Uchôa, S. C. P.; Fernandes, V. L. B. Recomendações de adubação e calagem para o estado do Ceará. Fortaleza: UFC, 1993. 247p.
Bernardo, S.; Soares, A. A.; Mantovani, E. C. Manual de irrigação. 8.ed. Viçosa: Editora UFV, 2008. 625p.

Carlin, S. D.; Rhein, A. F. de L.; Santos, D. M. M. dos. Efeito simultâneo da deficiência hídrica e do alumínio tóxico no solo na cultivar IAC915155 de cana-de-açúcar. Semina: Ciências Agrárias, v.33, p.553-564, 2012. https://doi.org/10.5433/1679-0359.2012v33n2p553

Caron, B. O. I.; Perrando, E. R.; Schmidt, D. I.; Manfron, P. A. I.; Behling, A.; Elli, E. F. I.; Eloy, E. Relações fisiológicas em mudas de pata-de-vaca (Bauhinia forficata Link). Revista Brasileira de Plantas Medicinais, v.16, p.196-201, 2014. https://doi.org/10.1590/ S1516-05722014000200005

Cruz, J. L.; Pelacani, C. R.; Soares Filho, W. S.; Castro Neto, M. T.; Coelho, E. F.; Dias, A. T.; Paes, R. A. Produção e partição de matéria seca e abertura estomática do limoeiro 'Cravo' submetido a estresse salino. Revista Brasileira de Fruticultura, v.25, p.528-531, 2003. https://doi.org/10.1590/S0100-29452003000300042

Fernandes, E. T.; Cairo, P. A. R.; Novaes, A. B. de. Respostas fisiológicas de clones de eucalipto cultivados em casa de vegetação sob deficiência hídrica. Ciência Rural, v.45, p.29-34, 2015. https://doi. org/10.1590/0103-8478cr20120152

Katerji, N.; Mastrorilli, M.; Lahmer, F. Z.; Maalouf, F.; Oweis, T. Faba bean productivity in saline-drought conditions. European Journal of Agronomy, v. 35, p.2-12, 2011. https://doi.org/10.1016/j. eja.2011.03.001

Lacerda, C. F. de; Neves, A. L. R.; Guimarães, F. V. A.; Silva, F. L. B. da; Prisco, J. T.; Gheyi, H. R. Eficiência de utilização de água e nutrientes em plantas de feijão-de-corda irrigada com água salina em diferentes estádios de desenvolvimento. Engenharia Agrícola, v.29, p.221-230, 2009. https://doi.org/10.1590/S010069162009000200005

Nascimento, R. do; Nascimento, D. A. M. do; Silva, D. A. da; Alves, A. G. Índice SPAD e partição de biomassa em plantas de feijãocaupi submetidas ao estresse salino. Revista Educação Agrícola Superior, v.27, p.128-132, 2012. https://doi.org/10.12722/0101756X.v27n02a09

Negrão, S.; Schmöckel, S. M.; Tester, M. Evaluating physiological responses of plants to salinity stress. Annals of Botany, v.119, p.111, 2017. https://doi.org/10.1093/aob/mcw191

Oliveira, F. N.; Torres, S. B.; Bebedito, C. P. Caracterização botânica e agronômica de acessos de feijão-fava, em Mossoró, RN. Revista Caatinga, v.24, p.143-148, 2011.

Orsini, F.; Alnayef, M.; Bona, S.; Maggio, A.; Gianquinto, G. Low stomatal density and reduced transpiration facilitate strawberry adaptation to salinity. Environmental and Experimental Botany, v.81, p.1-10, 2012. https://doi.org/10.1016/j.envexpbot.2012.02.005

Passos, C. D.; Passos, E. E. M.; Prado, C. H. B. de A. Comportamento sazonal do potencial hídrico e das trocas gasosas de quatro variedades de coqueiro-anão. Revista Brasileira de Fruticultura, v.27, p.248254, 2005. https://doi.org/10.1590/S0100-29452005000200016

Prazeres, S. da S.; Lacerda, C. F. de; Barbosa, F. E. L.; Amorim, A. V.; Araújo, I. C. da S.; Cavalcante, L. F. Crescimento e trocas gasosas de plantas de feijão-caupi sob irrigação salina e doses de potássio. Revista Agro@mbiente On-line, v.9, p.111-118, 2015. https://doi. org/10.18227/1982-8470ragro.v9i2.2161

Rhoades, J. D.; Kandiah, A.; Mashali, A. M. Uso de águas salinas para produção agrícola. Campina Grande: UFPB, 2000. 117p. Irrigação e Drenagem, 48 
Silva, A. R. A.; Bezerra, F. M. L.; Lacerda, C. F.; Sousa, C. H. C.; Chagas, K. L. Pigmentos fotossintéticos e potencial hídrico foliar em plantas jovens de coqueiro sob estresses hídrico e salino. Revista Agro@mbiente On-line, v.10,p.317-325, 2016. https://doi. org/10.18227/1982-8470ragro.v10i4.3650

Silva, E. N. da; Ribeiro, R. V.; Ferreira-Silva, S. L.; Viégas, R. A.; Silveira, J. A. G. Salt stress induced damages on the photosynthesis of physic nut young plants. Scientia Agricola, v.68, p.62-68, 2011. https://doi. org/10.1590/S0103-90162011000100010

Silva, F. de A. S. e; Azevedo, C. A. V. de. The Assistat software version 7.7 and its use in the analysis of experimental data. African Journal of. Agricultural Research, v.11, p.3733-3740, 2016. https://doi. org/10.5897/AJAR2016.11522

Silva, F. G. da; Dutra, W. F.; Dutra, A. F.; Oliveira, I. M. de; Filgueiras, L. M. B.; Melo, A. S. de. Trocas gasosas e fluorescência da clorofila em plantas de berinjela sob lâminas de irrigação. Revista Brasileira de Engenharia Agrícola e Ambiental, v.19, p.946-952, 2015. https:// doi.org/10.1590/1807-1929/agriambi.v19n10p946-952

Silva, M. A.; Santos, C. M. dos; Vitorino, H. dos S.; Rhein, A. F. de L. Pigmentos fotossintéticos e índice spad como descritores de intensidade do estresse por deficiência hídrica em cana-de-açúcar. Bioscience Journal, v.30, p.173-181, 2014.

Silva, M. de A.; Santos, C. M. dos; Arantes, M. T.; Brunelli, M. C.; Holanda, L. A de. Respostas fisiológicas de cultivares de cana-deaçúcar submetidas à deficiência hídrica e a reidratação. Revista Caatinga, v.26, p.28-35, 2013.
Silveira, H. M.; Ferreira, E. A.; Silva, D. V.; Castro Neto, M. D.; Carvalho, F. P.; Santos, J. B.; Silva, A. A. Características fisiológicas de cultivares de mandioca após aplicação do mesotrione. Planta Daninha, v.31, p.403-409, 2013. https://doi.org/10.1590/S010083582013000200018

Snyder, R. L. Equation for evaporation pan to evapotranspiration conversions. Journal of Irrigation and Drainage Engineering, v.118, p.977-980, 1992. https://doi.org/10.1061/(ASCE)07339437(1992)118:6(977)

Soares, L. A. dos A.; Furtado, G. de F.; Andrade, E. M. G. de; Sousa, J. R. M. de; Guerra, H. O. C.; Nascimento, R. do. Troca de $\mathrm{CO}_{2}$ do feijão-caupi irrigado com água salina e fertilização nitrogenada. Agropecuária Científica no Semi-Árido, v.9, p.30-37, 2013.

Soares, M. M.; Santos Júnior, H. C.; Simões, M. G.; Pazzin, D.; Silva, L. J. da. Estresse hídrico e salino em sementes de soja classificadas em diferentes tamanhos. Pesquisa Agropecuária Tropical, v.45, p.370-378, 2015. https://doi.org/10.1590/1983-40632015v4535357 Sousa, G. G. de; Viana, T. V. de A.; Lacerda, C. F. de; Azevedo, B. M. de; Silva, G. L. da; Costa, F. R. B. Estresse salino em plantas de feijãocaupi em solo com fertilizantes orgânicos. Revista Agro@mbiente On-line, v.8, p.359-367, 2014. https://doi.org/10.5327/Z19828470201400031824

Taiz, L.; Zeiger, E.; Møller, I.; Murphy, A. Fisiologia e desenvolvimento vegetal. 6.ed. Porto Alegre: Artmed, 2017. 888p. 